\title{
Electrochemical Determination of Rifampicin Based on Its Oxidation Using Multi-Walled Carbon Nanotube-Modified Glassy Carbon Electrodes
}

\section{Çok Duvarlı Karbon Nanotüp Modifiye Camsı Karbon Elektrot Kullanılarak Rifampisinin Oksidasyonuna Dayalı Elektrokimyasal Tayini}

\author{
(D) Dilek KUL \\ Karadeniz Technical University Faculty of Pharmacy, Department of Analytical Chemistry, Trabzon, Turkey
}

\begin{abstract}
Objectives: The aim of the study was to investigate the electrochemical behavior of rifampicin (RIF) in the anodic direction using multi-walled carbon nanotube (MWCNT)-modified glassy carbon electrodes.

Materials and Methods: The anodic investigation of RIF was carried out with cyclic, differential pulse, and square wave voltammetry. A threeelectrode system consisting of a glassy carbon electrode with a modification by MWCNTs as the working electrode, a platinum wire as the counter electrode, and an $\mathrm{Ag} / \mathrm{AgCl}$ electrode as reference was used for the experiments.

Results: The anodic process of RIF was irreversible and diffusion controlled. Linear responses were obtained between 0.04 and $10 \mu \mathrm{M}$ for both techniques in acetate buffer ( $\mathrm{pH}$ 3.5) as supporting electrolyte. The limit of detection values were 7.51 and $11.3 \mathrm{nM}$ for differential pulse and square wave voltammetry, respectively. The repeatability, reproducibility, precision, and accuracy of the proposed methods were also investigated. Determination of RIF was carried out on its pharmaceutical dosage forms and the results were compared with those from other electrochemical sensors and the liquid chromatographic and spectrophotometric methods in the literature.

Conclusion: These validated techniques provided selective, rapid, sensitive, precise, and cheap determination of RIF as alternative techniques to the liquid chromatographic and spectrophotometric methods in therapeutic drug monitoring.
\end{abstract}

Key words: Rifampicin, voltammetry, multi-walled carbon nanotubes, glassy carbon electrode, pharmaceuticals

öz

Amaç: Bu çalışmanın amacı, rifampisinin (RIF) elektrokimyasal davranışını çok duvarlı karbon nanotüp (MWCNT) ile modifiye edilmiş camsı karbon elektrotlar kullanarak anodik yönde incelemekti.

Gereç ve Yöntemler: RIF'nın anodik incelemesi dönüșümlü, diferansiyel puls ve kare dalga voltametri teknikleri ile yapılmıștır. Çalıșma elektrotu olarak MWCNT'nin bir modifikasyonuna sahip camsı bir karbon elektrot, karşı elektrot olarak bir platin tel ve referans olarak bir Ag/AgCl elektrotundan oluşan üç elektrotlu sistem, deneyler için kullanılmıştır.

Bulgular: RIFn'ın anodik süreci geri dönüşümsüz ve difüzyon kontrollüydü. Destek elektrolit olarak asetat tamponunda ( $\mathrm{pH} 3,5$ ) her iki teknik için de 0,04 ila $10 \mu \mathrm{M}$ arasında doğrusal cevaplar elde edilmiştir. Tespit limiti değerleri diferansiyel puls ve kare dalga voltametri teknikleri için sırasıyla 7,51 ve 11,3 nM olarak bulunmuștur. Önerilen yöntemlerin tekrarlanabilirliği, tekrar üretilebilirliği, kesinliği ve doğruluğu da incelenmiștir. RIF'ın tayini, farmasötik dozaj formlarından yapılmıştır ve sonuçlar, literatürdeki diğer elektrokimyasal sensörler ve ayrıca sıvı kromatografik ve spektrofotometrik yöntemlerle karşılaştırılmıştır.

Sonuç: Bu valide edilmiş teknikler, terapötik ilaç izlemede sıvı kromatografik ve spektrofotometrik yöntemlere alternatif teknikler olarak rifampisinin seçici, hızlı, hassas, kesin ve ucuz bir şekilde tayinini sağlamıştır.

Anahtar kelimeler: Rifampisin, voltametri, çok duvarlı karbon nanotüp, camsı karbon elektrot, farmasötikler

*Correspondence: E-mail: dilekk@ktu.edu.tr, Phone: +90 4623778821 ORCID-ID: orcid.org/0000-0002-8665-9417

Received: 25.02.2019, Accepted: 20.06.2019

๑Turk J Pharm Sci, Published by Galenos Publishing House. 


\section{INTRODUCTION}

Rifampicin (RIF), a semisynthetic derivative of rifamycin, is a macrocyclic antibiotic used to treat bacterial infections such as tuberculosis, leprosy, and Legionnaire's disease.' This drug, whose major activity is against mycobacteria, inhibits DNAdependent RNA polymerase in susceptible bacteria by forming a stable complex with the enzyme. Inhibition of the initiation of RNA synthesis by binding to the $\beta$-subunit of RNA polymerase results in the death of the cell. ${ }^{2}$ It is generally used with other antibiotics to expand the antibacterial effect and thus various infections originating from both intracellular and extracellular organisms can be treated. 3,4 Although RIF is one the most potent antibiotics used for the treatment of tuberculosis, the bacteria quickly develop resistance to RIF. In order to prevent the development of resistance, RIF is used in combination with other effective antimycobacterial agents such as isoniazid and ethambutol. ${ }^{2}$ RIF is not used for the treatment of viral infections such as colds and flu.

RIF has some adverse effects such as nausea, vomiting, loss of appetite, diarrhea, liver problems, and allergic reactions. The most serious adverse effect of RIF is hepatotoxicity, causing liver damage. In addition, RIF causes orange coloration of body fluids such as urine, sweat, and tears.

RIF has a heterocyclic structure containing naphthoquinone, giving it its characteristic orange color. Its chemical name is 3-(4-methylpiperazinyliminomethyl) rifamycin SV (Figure 1). RIF binds the bacterial RNA polymerase with the four hydroxyl groups forming hydrogen bonds with amino acid residues on the protein. ${ }^{2}$

RIF is usually administered orally, rapidly absorbed, and distributed to the body. The half-life of RIF is 2-3 h. Taking RIF with meals significantly decreases its absorption. RIF is quickly hydrolyzed after absorption and completely eliminated from the body through urine and mostly feces after about 6 h. ${ }^{5}$

Some studies are found in the literature for the determination of RIF using high performance liquid chromatography (HPLC), ${ }^{6-}$ 10 LC-mass spectrometry," Raman spectroscopy, ${ }^{12}$ Nuclear magnetic resonance spectroscopy, ${ }^{13}$ and ultraviolet-visible spectrophotometry. ${ }^{14}$ Electrochemical studies of RIF have also been performed, which studied both in the direction of oxidation using some unmodified ${ }^{15,16}$ and modified electrodes ${ }^{17-21}$

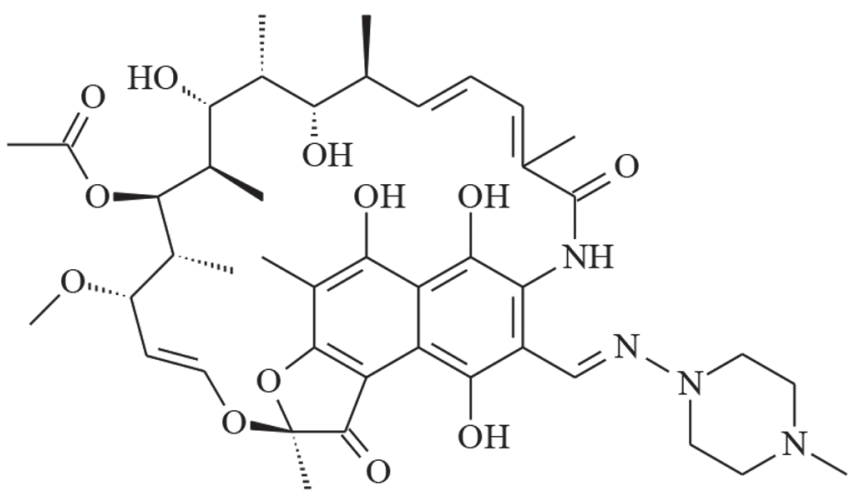

Figure 1. Molecular structure of rifampicin and in the direction of reduction. 22,23 The older studies on RIF were based on its electrochemical reduction using a mercury drop electrode by differential pulse polarography ${ }^{22}$ and differential pulse adsorptive stripping voltammetry (DPAdSV). ${ }^{23}$ In later years (between 2004 and 2017), RIF was studied in the direction of oxidation. In one previous study, ${ }^{15}$ a carbon paste electrode was used for the determination of RIF and isoniazid by cyclic and square wave voltammetry. Adsorptive stripping voltammetry was also used for both RIF and rifamycin at renewable pencil graphite electrodes. ${ }^{16}$ Some modifications such as a hollow manganese oxideamesoporous silica oxide core-shell nanohybrid at a disposable carbon paste microelectrode, ${ }^{17}$ nickel hydroxide nanoparticles-reduced graphene oxide nanosheets film at a glassy carbon (GC) electrode, ${ }^{19}$ and polyvinyl pyrrolidone capped $\mathrm{CoFe}_{2} \mathrm{O}_{4} @ \mathrm{CdSe}$ core shell at a GC electrode ${ }^{20}$ were also used for the sensitive determination of RIF.

Most of the chromatographic and spectrophotometric methods in the literature require expensive instrumentation and involve high running costs. Electrochemical methods ensure simple, sensitive, cheap, and fast analysis and determination of drugs. In addition, the electrochemical properties of drugs help us to understand their metabolic fate or in vivo redox processes and pharmacological activity. Although modified electrodes provide highly sensitive determination of drugs, it is important that procedures for the modification of electrodes are easy to prepare and stable. For this reason, new modification methods for electrodes and voltammetric methods are constantly investigated to find the best results for the electroactive components.

Carbon nanotubes (CNTs) were discovered in 1991 and have fascinating electronic, magnetic, and mechanical properties. Their unique structure making them strong and rigid means they are suitable for use in the fields of medicine (drug delivery, treatments of diseases, monitoring of cells), manufacturing, electronics, optics, nanotechnology, and other materials science and technology. ${ }^{24}$ In addition, electrically conductive CNTs can also be used as a carrier of some specific drugs by attaching to the drugs and targeting certain types of cells such as cancer cells. ${ }^{25}$ CNTs are generally categorized as singlewalled CNTs and multiwalled CNTs (MWCNTs). ${ }^{26}$ MWCNTs were used in the present study since they are well-known materials widely used since 1991 due to their superior chemical and physical properties mentioned above. In addition, MWCNTs have a very strong and elastic structure due to the $\mathrm{sp}^{2}$ bonds between carbon atoms. These strong bonds ensure that MWCNTs have very high electric conductivity and resistance to high temperatures. ${ }^{26}$

The aim of the present study was to conduct electrochemical analysis and sensitive determination of the antibacterial drug RIF through its oxidation with a functionalized MWCNT-modified GC electrode by using cyclic voltammetry (CV), differential pulse voltammetry (DPV), and square wave voltammetry (SWV). Developing fully validated and rapid methods using a simply modified GC electrode will ensure more sensitive 
determination of RIF based on its oxidation compared to the studies in the literature providing the direct determination of RIF from pharmaceutical dosage forms without any sample pretreatment.

\section{MATERIALS AND METHODS}

\section{Materials}

RIF and its pharmaceutical dosage form (Rifcap ${ }^{\circledR}$, including 300 mg of RIF per capsule) were kindly supplied by Koçak Farma (Istanbul, Turkey). $\mathrm{COOH}$ functionalized MWCNTs were from NanoLab, U.S.A., with $>95 \%$ purity, $15 \pm 5 \mathrm{~nm}$ diameter, and 1-5 $\mu \mathrm{m}$ length. The other chemicals were analytical grade (Merck or Sigma) and used without any purification.

Stock solutions of RIF $\left(1.0 \times 10^{-3} \mathrm{M}\right)$ were prepared in ultrapure water and stored in the dark at $+4^{\circ} \mathrm{C}$. Voltammetric experiments for RIF were performed using working solutions of RIF prepared by direct dilution of the stock solution with the selected supporting electrolyte. The supporting electrolytes were phosphate buffer ( $\mathrm{PB}, 0.1 \mathrm{M} \mathrm{NaH}_{2} \mathrm{PO}_{4} .2 \mathrm{H}_{2} \mathrm{O} ; 0.1 \mathrm{M} \mathrm{Na}_{2} \mathrm{HPO}_{4} ; \mathrm{pH}$ 5.5-8.0), Britton-Robinson buffer [(BRB), $0.04 \mathrm{M} \mathrm{H}_{3} \mathrm{BO}_{3} ; 0.04$ $\left.\mathrm{M} \mathrm{H}_{3} \mathrm{PO}_{4} ; 0.04 \mathrm{M} \mathrm{CH}_{3} \mathrm{COOH} ; \mathrm{pH} 2.0-8.0\right)$ ], and acetate buffer

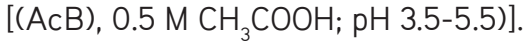

\section{Apparatus}

Voltammetric measurements were recorded using a computercontrolled Autolab type 2 potentiostat/galvanostat with Nova 1.10 software (Metrohm, the Netherlands) at room temperature. The three-electrode system consisted of a GC electrode (BASi, f: $3.0 \mathrm{~mm}$ diameter) with modification by MWCNTs as the working electrode, a platinum wire as the counter electrode (BASi), and a $\mathrm{Ag} / \mathrm{AgCl}$ electrode (BASi, 3.0 M KCl) as reference. The bare GC electrode was polished with aqueous slurry of alumina powder (f: $0.01 \mu \mathrm{m}$ ) on a damp smooth polishing cloth before the modification.

The operating conditions for DPV were as follows: pulse amplitude, $50 \mathrm{mV}$; pulse width, $50 \mathrm{~ms}$; scan rate, $2 \mathrm{mV} \mathrm{s}^{-1}$; for SWV: pulse amplitude, $25 \mathrm{mV}$; frequency, $10 \mathrm{~Hz}$; step potential, $1 \mathrm{mV}$.

The surface morphology of the bare GC and MWCNT-modified GC electrodes was determined using scanning electron microscopy (SEM) with a LEO 438 VP (LEO Instruments, UK) in high vacuum mode at $20 \mathrm{kEV}$.

The $\mathrm{pH}$ measurements were made using a model HI2211 pHmeter (Hanna, Romania) with a combined electrode (glass/ reference electrodes) with an accuracy of $\pm 0.05 \mathrm{pH}$ at room temperature.

Sartorius Arium ${ }^{\circledR}$ ProUV ultrapure water (resistivity $\geq 18 \mathrm{M} \Omega$ $\mathrm{cm}$ ) was used for the preparation of all solutions.

\section{Preparation of MWCNT-modified electrodes}

Functionalized MWCNTs were weighed and dispersed in dimethyl formamide (DMF) as $0.2 \%\left(\mathrm{mg} \mathrm{mL}^{-1}\right)$. The dispersion was sonicated for $4 \mathrm{~h}$ to ensure a homogeneous mixture. Before the coating, the bare GC electrode was polished with $\mathrm{Al}_{2} \mathrm{O}_{3}$ slurry on a polishing pad and rinsed with nanopure water.
Then a specified amount of MWCNT/DMF dispersion, 1.5, 2.5, 3.5, and $5.0 \mu \mathrm{L}$, was dropped on the surface of the GC electrode and it was left to dry overnight at room temperature to obtain the MWCNT-modified GC electrode, labeled as MWCNT/GC electrode.

\section{Voltammetric studies}

All working solutions of RIF were prepared freshly just before the experiments and protected from light. The calibration equations were obtained from both DP and SW voltammograms by plotting the peak current against RIF concentration. The ruggedness, precision, and accuracy of the methods were checked by assaying five replicate samples on the same day and different days over a week. The ruggedness and the precision of the methods were checked with relative standard deviations (RSD\%). The relative errors (Bias\%), which describe the deviation from the expected results, were also calculated to check the accuracy and the precision of the developed methods. ${ }^{27,28}$

\section{Capsule assay procedure}

The contents of ten capsules of Rifcap ${ }^{\circledR}$, including 300 mg of RIF per capsule, were weighed. An appropriate amount of the contents was taken and diluted to $25 \mathrm{~mL}$ with ultrapure water to prepare a stock solution of $1.0 \times 10^{-3} \mathrm{M}$ RIF. The solution was sonicated for $15 \mathrm{~min}$ to complete dissolution and then left for $10 \mathrm{~min}$ to allow the insoluble parts to settle to the bottom. The working solutions were prepared by taking from the clear supernatant liquor and diluting with the selected supporting electrolyte. ${ }^{29}$ The RIF amount per capsule was calculated using the corresponding calibration plots of both DPV and SWV.

The other components of the matrix of the pharmaceutical dosage forms can show any interference during the determination of RIF. For this purpose, recovery studies were carried out to check the accuracy of the developed methods using the standard addition method. ${ }^{27}$ A known amount of RIF was added to the preanalyzed RIF capsule and then the calculations were conducted using the related regression equations of the calibration plots for both techniques.

\section{Statistical analysis}

Validation of the proposed method was carried out by statistical analysis of data obtained during the experiments to define the performance and limitations of the method. Based on the statistical analysis, the analytical limits, precision, and accuracy of the proposed methods were determined.

\section{RESULTS AND DISCUSSION}

An easily modified GC was used to ensure more sensitive determination of RIF based on its oxidation in comparison to the studies in the literature. In the first step, coating of the GC electrode was performed using 0.2\% (mg mL $\left.{ }^{-1}\right)$ MWCNT/DMF dispersion. For this purpose, an amount of the dispersion was dropped using a micropipette on the surface of the GC electrode. After the electrode dried, the surface was activated by cycling the potential in the region from -0.8 to $+1.2 \mathrm{~V}$ vs. $\mathrm{Ag} / \mathrm{AgCl}$ at a scan rate of $100 \mathrm{mV} \mathrm{s}^{-1}$ for 15 cycles in BRB solution at $\mathrm{pH}$ 5.0. 
The electrochemical responses of $20 \mu \mathrm{M}$ RIF were compared for both the bare GC electrode and $2.5 \mu \mathrm{L}$ of $0.2 \%$ MWCNT/ DMF-coated GC electrode using CV and DPV in BRB solution at $\mathrm{pH}$ 5.0. The peak currents of RIF obtained with the MWCNT/ $\mathrm{GC}$ electrode were 1.86 times and 4.52 times higher than those bare GC electrodes for CV and DPV (Figure 2), respectively.

The coating amount of MWCNT/DMF dispersion was selected for the best electrochemical analysis of RIF. For this purpose, $1.5,2.5,3.5$, and $5.0 \mu \mathrm{L}$ of the $0.2 \%$ MWCNT/DMF dispersion were dropped on the surface of the GC electrode and the peak currents of RIF were analyzed by CV, DPV, and SWV. The highest peak current with the best peak shape was obtained with $1.5 \mu \mathrm{L}$ of $0.2 \%$ MWCNT/DMF dispersion; thus, the GC electrode was modified with this amount for the further studies of RIF.

\section{Surface characterization}

SEM was used to investigate the surface morphology of both the bare GC and MWCNT-modified GC electrodes. Figures $3 A$ and $3 B$ show SEM images of the bare $G C$ electrode and $G C$ electrode coated with $1.5 \mu \mathrm{L}$ of $0.2 \%$ MWCNT/DMF dispersion, respectively. As can be seen in Figure 3B, densely packed and popcorn-like MWCNTs were used for coating and formed a porous structure onto the surface of the GC electrode.

\section{Effect of $\mathrm{pH}$ and scan rate}

Electrochemical characterization of RIF was carried out with the MWCNT/GC electrode. For this purpose, cyclic voltammograms of RIF were obtained at a scan rate of $100 \mathrm{mV} \mathrm{s}^{-1}$ in the potential
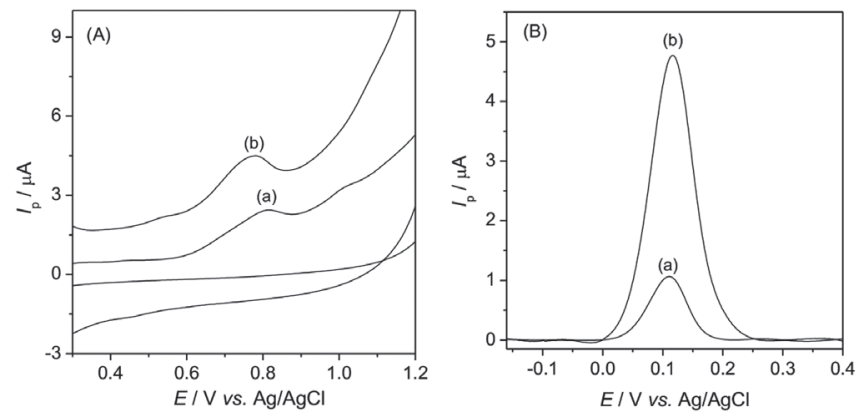

Figure 2. (A) Cyclic and (B) differential pulse voltammograms of $20 \mu \mathrm{M}$ of $\mathrm{RIF}$ in BRB solution at $\mathrm{pH} 5.0$ obtained at (a) bare GC and (b) $2.5 \mu \mathrm{L}$ of $0.2 \%$ MWCNT/DMF-coated GC electrodes

RIF: Rifampicin, BRB: Britton-Robinson buffer, GC: Glassy carbon, MWCNT: Multiwalled carbon nanotube, DMF: Dimethyl formamide

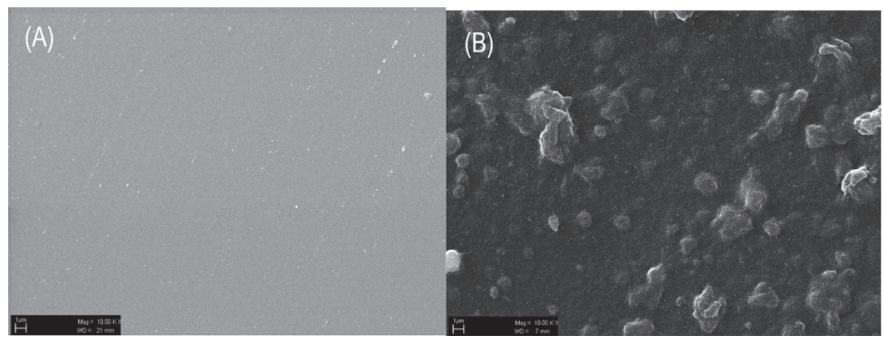

Figure 3. SEM images of (A) bare GC and (B) $1.5 \mu \mathrm{L}$ of $0.2 \%$ MWCNT/DMFcoated GC electrodes, scale bar: $1 \mu \mathrm{m}$

SEM: Scanning electron microscopy, GC: Glassy carbon, MWCNT: Multi-walled carbon nanotube, DMF: Dimethyl formamide range from -0.6 to $+1.1 \mathrm{~V}$ in different buffer solutions at $\mathrm{pH}$ values between 2.0 and 8.0. Buffer solutions with $\mathrm{pH}$ values higher than 8.0 were not used in order to prevent the loss of MWCNT coatings on the surface of the GC electrode.

According to the cyclic voltammograms (Figure 4A), an anodic peak having a high peak current at all pHs was observed at around $+0.9 \vee$ (labeled as $0 \times 1$ ), showing an irreversible oxidation process. At around $+0.3 \mathrm{~V}$, another anodic peak having a relatively high peak current was also seen (labeled as $0 \times 2$ ), showing a reversible redox process. With increasing $\mathrm{pH}$, additional anodic and cathodic waves appeared at the peak potentials between -0.2 and $+0.2 \mathrm{~V}$. Differential pulse (Figure $4 \mathrm{~B}$ ) and square wave (Figure $4 \mathrm{C}$ ) voltammograms were also obtained at all pHs to investigate the anodic peaks of RIF for its quantitative determination. The Ox1 peak was not observed at around $+0.9 \mathrm{~V}$ in DP or SW voltammograms. However, the Ox2 peak at around $+0.3 \mathrm{~V}$ was seen as a symmetrical and well-defined anodic peak with a high peak current. Another anodic peak separated well from the 0x2 peak was observed at around $-0.1 \mathrm{~V}$ at $\mathrm{pH}$ s lower than 5.0 , whereas this peak was intercalated with the Ox2 peak and observed as a shoulder at pHs higher than 5.0.

The reversible redox process including the $0 \times 2$ anodic peak (Figure 4A) may be due to the hydroquinone-quinone redox system of the 6,9-dihydroxynaphtalene moiety to the corresponding naphthoquinone of RIF. ${ }^{15}$ The irreversible oxidation peak labeled $0 \times 1$ (Figure $4 \mathrm{~A}$ ) may be attributed to the irreversible oxidation of the piperazinyl-imino moiety. ${ }^{21}$

Peak potentials of both $0 \times 1$ and $0 \times 2$ peaks shifted to less positive potentials with increasing $\mathrm{pH}$ from 2.0 to 8.0 for all voltammetric techniques. The shift values were $0.285 \mathrm{~V}$ for the Ox1 peak with $C V$ and $0.256 \mathrm{~V}, 0.266 \mathrm{~V}$, and $0.275 \mathrm{~V}$ for the Ox2 peak with CV, DPV, and SWV, respectively. These negative shifts showed that the decrease in the concentration of $\mathrm{H}_{3} \mathrm{O}^{+}$in the buffer solutions allowed easier oxidation of RIF due to its weak acidic nature.

The relationship between $\mathrm{pH}$ and peak potential and peak current of $40 \mu \mathrm{M}$ RIF was studied using CV for the Ox1 peak and using CV, DPV, and SWV for the Ox2 peak. Graphs of $E_{p}-$
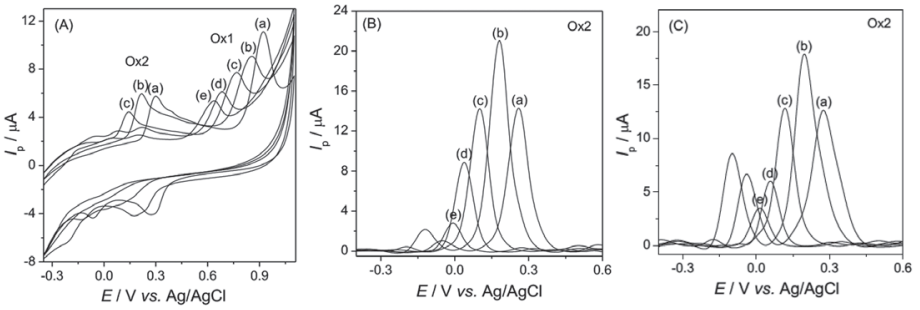

Figure 4. Voltammograms of $40 \mu \mathrm{M}$ RIF obtained with (A) CV, (B) DPV (for Ox2 peak, baseline corrected), and (C) SWV (for Ox2 peak, baseline corrected) in (a) BRB at $\mathrm{pH}$ 2.0, (b) $\mathrm{AcB}$ at $\mathrm{pH} 3.5$, (c) $\mathrm{PB}$ at $\mathrm{pH}$ 5.5, (d) PB at $\mathrm{pH} 7.0$, and (e) BRB at $\mathrm{pH} 8.0$ at the MWCNT/GC electrode. Scan rate: $100 \mathrm{mV} \mathrm{s}^{-1}$ for $\mathrm{CV}$

RIF: Rifampicin, CV: Cyclic voltammetry, DPV: Differential pulse voltammetry, SWV: Square wave voltammetry, BRB: Britton-Robinson buffer, MWCNT: Multi-walled carbon nanotube, GC: Glassy carbon 
$\mathrm{pH}$ for both $\mathrm{Ox} 1$ and $\mathrm{Ox} 2$ peaks using $\mathrm{CV}$ are given in Figures $5 \mathrm{~A}$ and $5 \mathrm{~B}$, respectively. The graphs obtained with DPV and SWV for the Ox2 peak were similar; thus, their graphs are not shown. According to all graphs, linear plots were obtained for both $0 \times 1$ and $0 \times 2$ peaks at $\mathrm{pHs}$ between 2.0 and 8.0, expressed by equations $1-4$.

$E_{p}(\mathrm{~V})=1.030-0.048 \mathrm{pH} ; \mathrm{r}=0.990, \mathrm{n}=10$ (for Ox1, obtained with CV) (1)

$E_{p}(\mathrm{~V})=0.365-0.041 \mathrm{pH} ; \mathrm{r}=0.991, \mathrm{n}=10$ (for Ox2, obtained with CV) (2)

$E_{p}(\mathrm{~V})=0.335-0.042 \mathrm{pH} ; \mathrm{r}=0.996, \mathrm{n}=10$ (for $0 \times 2$, obtained with DPV) (3)

$E_{p}(V)=0.345-0.042 \mathrm{pH} ; \mathrm{r}=0.992, \mathrm{n}=10$ (for $0 \times 2$, obtained with SWV) (4)

The negative slope values of the linear plots of the $E_{p}-\mathrm{pH}$ graphs in the $\mathrm{pH}$ range between 2.0 and 8.0 were between -41 and -48 $\mathrm{mV} \mathrm{pH}^{-1}$, showing that the numbers of electrons and protons might not be equal in the redox process of RIF. The slope of 59 $\mathrm{mV} \mathrm{pH}^{-1}$ is the theoretical value showing that the numbers of protons and electrons are equal. ${ }^{29}$

The effect of $\mathrm{pH}$ on the peak current $\left(I_{p}\right)$ of RIF was also investigated using CV, DPV and SWV for the Ox2 peak. Since the Ox1 peak was not observed in DP or SW voltammograms, quantitative determination of RIF was studied with only the Ox2 peak. According to the $I_{\mathrm{p}}-\mathrm{pH}$ graphs of the $0 \times 2$ peak, a single, well-defined, sharp, and symmetrical anodic peak (Figures 4B and $4 \mathrm{C}$ ) having the highest peak current was obtained in $\mathrm{AcB}$ at $\mathrm{pH} 3.5$ for both DPV (Figure $5 \mathrm{C}$ ) and SWV. For this reason, $\mathrm{AcB}$ solution at $\mathrm{pH} 3.5$ was selected as the supporting electrolyte for further studies.

The redox process of RIF was determined with scan rate studies using CV in the sweep range from 5 to $200 \mathrm{mV} \mathrm{s}^{-1}$ for $40 \mu \mathrm{M} \mathrm{RIF}$ in $\mathrm{AcB}$ at $\mathrm{pH}$ 3.5. The linear relationship between the square root of the scan rate $\left(v^{1 / 2}, \mathrm{mV} \mathrm{s}^{-1}\right)$ and the peak current $\left(I_{p^{\prime}} \mu \mathrm{A}\right)$ of RIF for the Ox2 peak demonstrated the diffusional behavior of RIF on the MWCNT/GC electrode (Equation 5). The graph between the logarithm of scan rate $(\log v)$ and the logarithm of peak current $\left(\log I_{p}\right)$ gave a straight line with a slope of 0.667 for the 0x2 peak (Equation 6). Theoretical values of 0.5 and 1.0 for the $\log v$ vs. $\log I_{p}$ graph express diffusion and adsorption controlled electrode process, respectively. ${ }^{30}$ The obtained slope of 0.667 showed that the process was diffusion controlled under some adsorptive effects. Due to the adsorptive effects, DPAdSV and square wave adsorptive stripping voltammetry were tested with the parameters of accumulation potential and accumulation time for the determination of RIF. However, these parameters could not be optimized and linear calibration graphs could not be obtained. For this reason, DPV and SWV were used for the determination studies of RIF.

$I_{p}(\mu \mathrm{A})=0.172 v^{1 / 2}\left(\mathrm{mV} \mathrm{s}^{-1}\right)-0.197 ; r=0.996, \mathrm{n}=8$ (for Ox2) (5)

$\log I_{p}(\mu \mathrm{A})=0.667 \log v\left(\mathrm{mV} \mathrm{s}^{-1}\right)-1.154 ; r=0.993, n=8$ (for $\left.0 \times 2\right)$ (6)

Determination of RIF by MWCNT/GC electrode

Determination of RIF was studied with the MWCNT/GC electrode using both DPV and SWV having good selectivity, high sensitivity, and low detection limits. All measurements were made for the anodic $0 \times 2$ peak in $A c B$ at $\mathrm{pH} 3.5$ as the supporting electrolyte. Calibration graphs were obtained between the concentration of RIF and the peak current of Ox2 for DPV and SWV. Figure 6 shows DP and SW voltammograms obtained with different concentrations of RIF.

The plots of the calibration graphs were linear in the range between 0.04 and $10 \mu \mathrm{M}$ for both DPV and SWV. At concentrations higher than $10 \mu \mathrm{M}$, the linearity was lost, probably due to the increase in the adsorption effect of RIF on the surface of the MWCNT/GC electrode. Besides linearity ranges, the values of slope, correlation coefficient, limits of detection (LOD) and quantification $(L O Q)$, repeatability (within day), reproducibility (between days), and precision were calculated for both techniques at MWCNT/GC electrodes. ${ }^{27,28}$ All values are listed in Table 1. Calibration graphs gave a linear plot with a slope of $0.799 \mu \mathrm{A} \mu \mathrm{M}^{-1}$ for DPV and two linear plots with slope values of $1.503 \mu \mathrm{A} \mu \mathrm{M}^{-1}$ and $0.714 \mu \mathrm{A} \mu \mathrm{M}^{-1}$ for SWV.

The $L O D$ and $L O Q$ values were calculated from the peak current of RIF using $L O D=3 \mathrm{~s} / \mathrm{m}$ and $L O Q=10 \mathrm{~s} / \mathrm{m}$ equations, where $\mathrm{s}$ is the standard deviation of the peak currents (three runs) and $m$ is the slope of the related calibration equation. ${ }^{27,31}$ The repetitive five DPV and SWV experiments in the same day (repeatability) and on different days over a week (reproducibility) obtained from different solutions containing RIF at the same concentration ( 4 $\mu \mathrm{M})$ gave the precision of the techniques. These within-day and
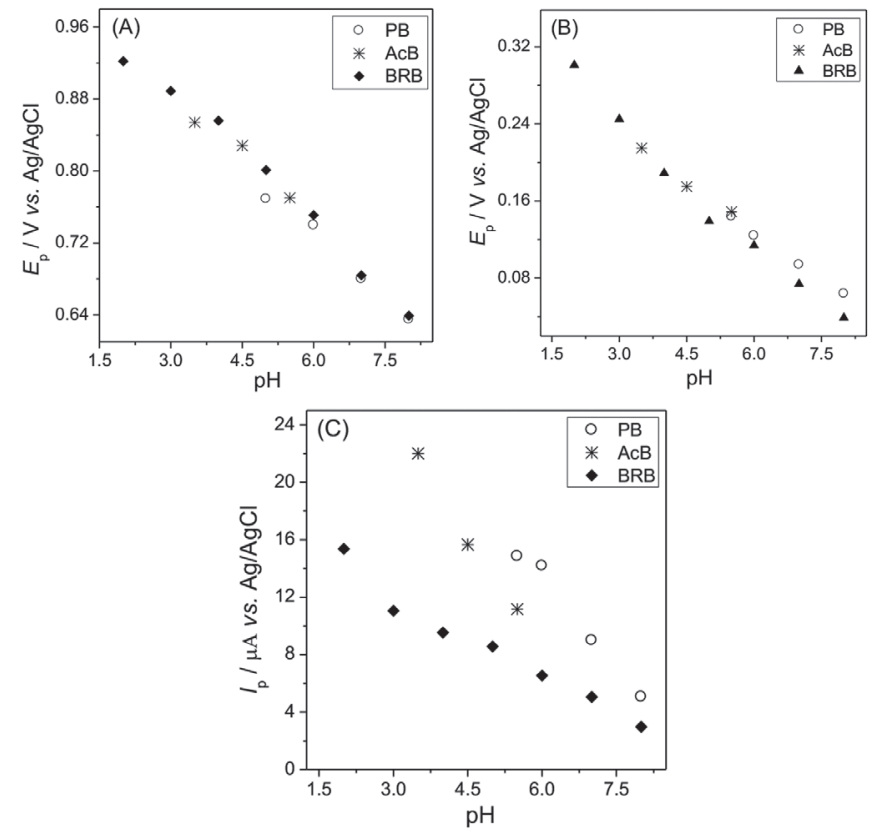

Figure 5. Effects of $\mathrm{pH}$ on the peak potentials for $\mathrm{O} \times 1(\mathrm{~A})$ and $\mathrm{O} \times 2(\mathrm{~B})$ and the peak currents for $\mathrm{O} \times 2(\mathrm{C})$ of RIF obtained with $\mathrm{CV}(\mathrm{A}$ and $\mathrm{B})$ and $\mathrm{DPV}$ (C) at the MWCNT/GC electrode. RIF concentration $40 \mu \mathrm{M}$ in $0.1 \mathrm{M} \mathrm{PB}$ (o), $0.5 \mathrm{M} \mathrm{AcB}(\mathrm{x})$, and $0.04 \mathrm{M} \mathrm{BRB}(\star)$

RIF: Rifampicin, CV: Cyclic voltammetry, DPV: Differential pulse voltammetry, MWCNT: Multi-walled carbon nanotube, GC: Glassy carbon, o PB: Phosphate buffer, x AcB: Acetate buffer, $\bullet$ BRB: Britton-Robinson buffer 
between-day precision, accuracy, and reproducibility values are presented as RSD\% (Table 1). RSD\% values lower than $1.5 \%$ demonstrated good precision, accuracy, and reproducibility.

\section{Stability of RIF}

The stability of RIF solutions was also studied over a month. Stock solution of RIF dissolved in ultrapure water was stored in the dark at $+4^{\circ} \mathrm{C}$. DP and SW voltammograms of the prepared
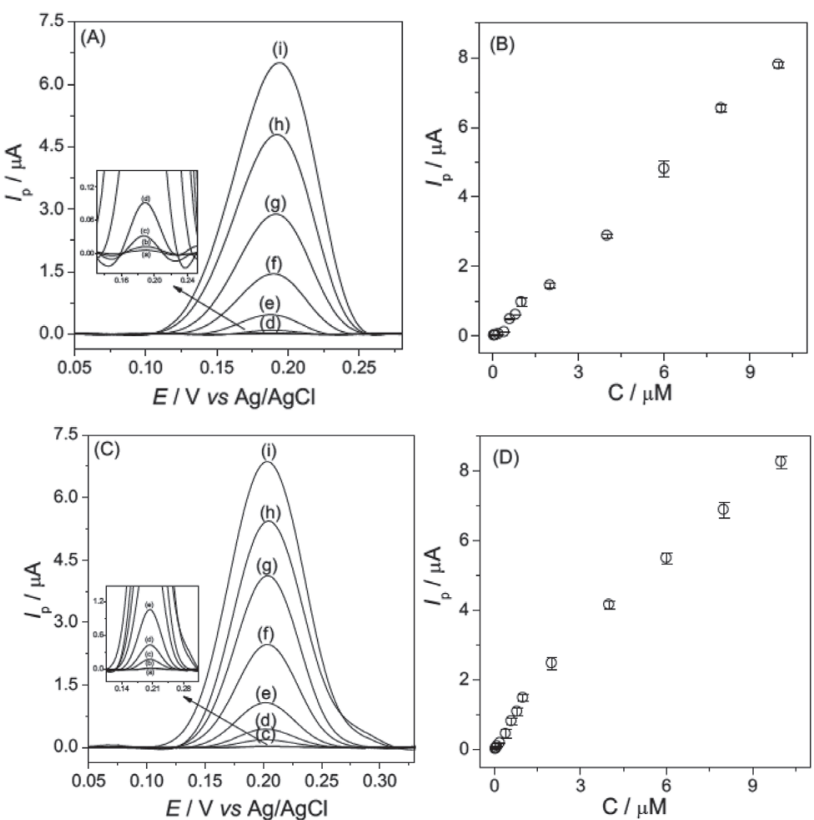

Figure 6. Baseline corrected (A) differential pulse and (C) square wave voltammograms obtained for the determination of (a) blank, (b) 0.06 $\mu \mathrm{M}$, (c) $0.2 \mu \mathrm{M}$, (d) $0.4 \mu \mathrm{M}$, (e) $0.8 \mu \mathrm{M}$, (f) $2.0 \mu \mathrm{M}$, (g) $4.0 \mu \mathrm{M}$, (h) $6.0 \mu \mathrm{M}$, and (i) $8.0 \mu \mathrm{M}$ of RIF in pH 3.5 AcB. Plots of the peak current $\left(/_{p}\right)$ vs. the concentration of RIF with error bars representing standard deviations for each concentration, calculated from (B) differential pulse and (D) square wave voltammograms

RIF: Rifampicin, AcB: Acetate buffer solutions containing the same RIF concentration in $\mathrm{AcB}$ at $\mathrm{pH}$ 3.5 were obtained. According to the voltammograms, decreases of $2.68 \%$ for DPV and $2.37 \%$ for SWV were observed at the peak currents of RIF after 4 weeks of storage. These low decrease values show that the solutions of RIF prepared by dissolving in ultrapure water can be used for up to 4 weeks. However, all solutions were freshly prepared every week to ensure the stability of RIF in the working solutions.

\section{Determination of RIF from pharmaceutical dosage forms}

The determination of RIF from its pharmaceutical dosage forms was studied to investigate the accuracy, selectivity, and precision of the developed voltammetric techniques with MWCNT/GC electrodes. For this purpose, the proposed DPV and SWV techniques were used to determine RIF in its capsules (300 mg RIF per capsule) for the prepared MWCNT/GC electrode. Pretreatment steps such as extraction and evaporation were not used before the voltammetric measurements. Recovery studies showed whether the excipients in pharmaceutical dosage forms caused any interference in the analysis of RIF. These studies were carried out by adding known amounts of standard RIF solution to the preanalyzed capsule solutions. The results are listed in Table 2 . These results showed that the proposed methods for the prepared MWCNT/GC electrode could be applied for the sensitive anodic determination of RIF from pharmaceutical dosage forms without any interference from the excipients.

The bias \% values were calculated to see the differences between the expected values obtained with DPV and SWV measurements and the true value (labeled RIF amount per capsule). Positive values of bias $\%$ indicated overestimation bias, meaning that the true value was slightly lower than the calculated values for both DPV and SWV (Table 2).

Table 1. Regression data of the calibration lines for quantitative determination of RIF in pH 3.5 AcB with DPV and SWV at the MWCNT/GC electrode

\begin{tabular}{|c|c|c|c|}
\hline \multirow{2}{*}{\multicolumn{2}{|c|}{ Measured potential (V) }} & DPV & SWV \\
\hline & & 0.193 & 0.203 \\
\hline \multicolumn{2}{|c|}{ Linearity range $(\mu \mathrm{M})$} & $0.04-10$ & $0.04-1.6$ and $1.6-10$ \\
\hline \multicolumn{2}{|c|}{ Slope of the calibration graph $\left(\mu \mathrm{A} \mu \mathrm{M}^{-1}\right)$} & $0.799 \pm 0.01$ & $1.503 \pm 0.04$ and $0.714 \pm 0.01$ \\
\hline \multicolumn{2}{|c|}{ Intercept $(\mu \mathrm{A})$} & $-0.059 \pm 0.04$ & $-0.078 \pm 0.02$ and $1.169 \pm 0.11$ \\
\hline \multicolumn{2}{|c|}{ Correlation coefficient } & 0.997 & 0.994 and 0.998 \\
\hline \multicolumn{2}{|c|}{$\operatorname{LOD}(\mu \mathrm{M})$} & $7.51 \times 10^{-3}$ & $1.13 \times 10^{-2}$ \\
\hline \multicolumn{2}{|c|}{$\mathrm{LOQ}(\mu \mathrm{M})$} & $2.50 \times 10^{-2}$ & $3.78 \times 10^{-2}$ \\
\hline \multirow{4}{*}{$\begin{array}{l}\frac{\Perp}{\Sigma} \\
\sum \\
\sum \\
v\end{array}$} & Repeatability of peak current (RSD\%) & 1.01 & 0.84 \\
\hline & Repeatability of peak potential (RSD\%) & 0.56 & 0.35 \\
\hline & Reproducibility of peak current (RSD\%) & 1.07 & 1.42 \\
\hline & Reproducibility of peak potential (RSD\%) & 0.60 & 0.42 \\
\hline
\end{tabular}

RIF: Rifampicin, AcB: Acetate buffer, SWV: Square wave voltammetry, MWCNT: Multi-walled carbon nanotube, GC: Glassy carbon, LOD: Limits of detection, LOQ: Limit of quantitation, RSD: Relative standard deviations, DPV: Differential pulse voltammetry, SWV: Square wave voltammetry 
Table 2. The results for the determination of RIF from capsule form and recovery experiments achieved in pH 3.5 AcB using the MWCNT/GC electrode

\begin{tabular}{lll} 
Parameters & DPV & SWV \\
\hline Labeled claim $(\mathrm{mg})$ & 300.00 & 300.00 \\
\hline Amount found* $(\mathrm{mg})$ & 300.32 & 300.36 \\
\hline RSD\% & 1.11 & 1.38 \\
\hline Bias\% & 0.11 & 0.12 \\
\hline Added $(\mathrm{mg})$ & $1.640 \times 10^{-2}$ & $1.640 \times 10^{-2}$ \\
\hline Found* $(\mathrm{mg})$ & $1.656 \times 10^{-2}$ & $1.660 \times 10^{-2}$ \\
\hline Average recovered $(\%)$ & 100.98 & 101.22 \\
\hline RSD\% of recovery & 1.68 & 2.40 \\
\hline Bias\% & 0.98 & 1.22 \\
\hline
\end{tabular}

*Obtained from five experiments, RIF: Rifampicin, AcB: Acetate buffer, MWCNT: Multi-walled carbon nanotube, GC: Glassy carbon, DPV: Differential pulse voltammetry, SWV: Square wave voltammetry, RSD: Relative standard deviations

\section{Comparison of the proposed methods}

The parameters of the validated DPV and SWV techniques for the MWCNT/GC electrode were compared with those of other sensors in the literature obtained for the determination of RIF in both the anodic ${ }^{15-18,21,32-35}$ and cathodic ${ }^{21,22,36-38}$ directions (Table 3). According to the results obtained in the anodic direction, a wider linear range was obtained in the present study compared to the studies in Table 3. Lower LODs were found only in two studies; ${ }^{18,32}$ however, the linear ranges of those studies were narrower. In addition, the electrode preparation procedures were long and complicated in some previous studies ${ }^{17,33-35}$ compared to the MWCNT/GC electrode used in the present study.

The results for RIF obtained in the direction of reduction in Table 3 showed that a wider linear range was found in the present study compared to the studies in the literature. ${ }^{21,37,38}$ Although a carbon paste electrode gave a wider linear range in a previous study, ${ }^{22}$ the LOD was higher than that in the present study. In another previous study, ${ }^{36}$ there was no information

Table 3. Compared parameters obtained using different electrochemical sensors for the determination of RIF in the anodic direction

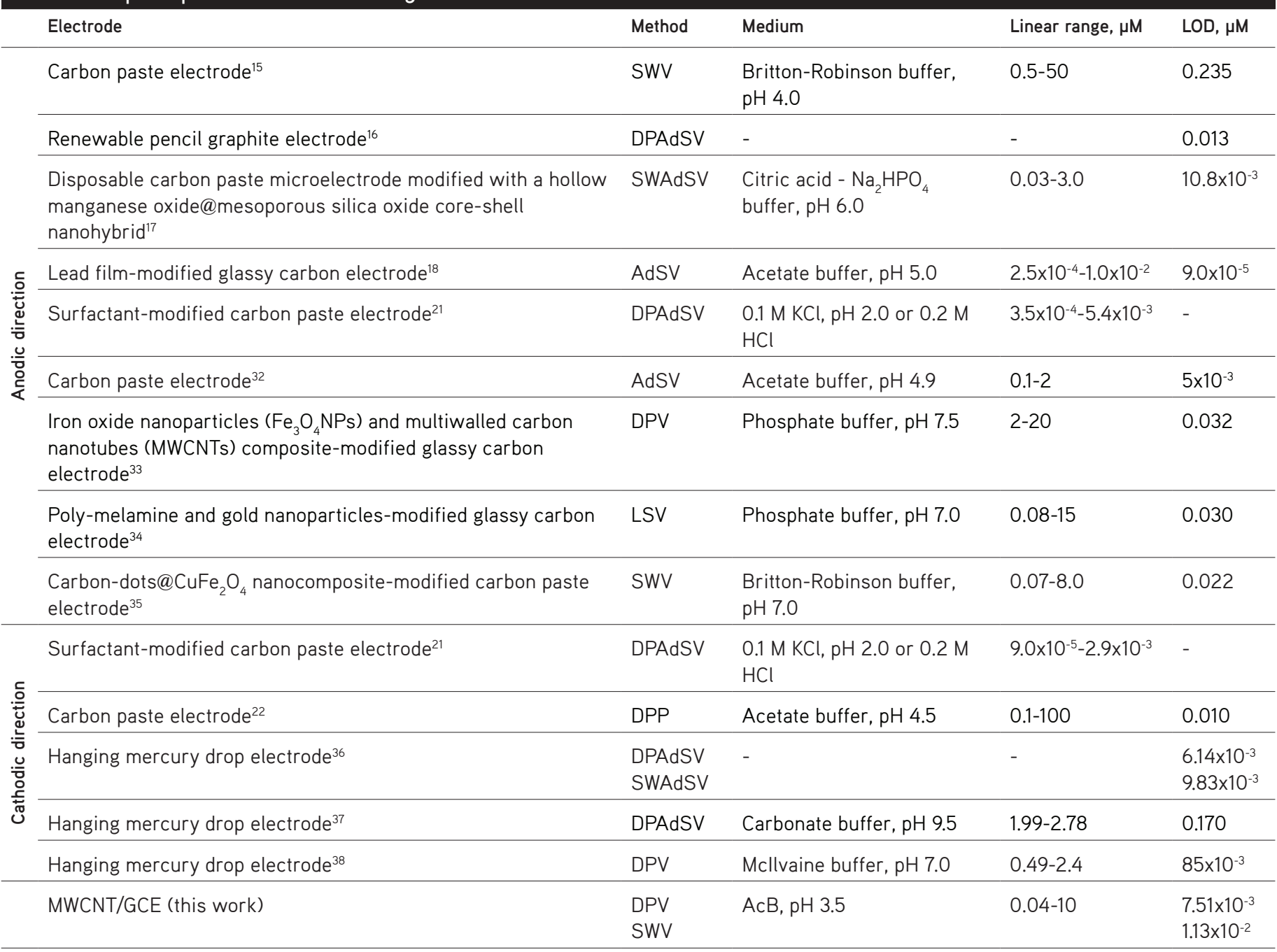

RIF: Rifampicin, AdSV: Adsorptive stripping voltammetry, DPAdSV: Differential pulse adsorptive stripping voltammetry, SWAdSV: Square wave adsorptive stripping voltammetry, LSV: Linear sweep voltammetry, DPP: Differential pulse polarography, LOD: Limits of detection, MWCNT: Multi-walled carbon nanotube, AcB: Acetate buffer 
about the linear range and the LOD was at the $\mathrm{nM}$ level as in the present study. The detection limits of the other studies in Table $3^{37,38}$ were higher compared to that of the MWCNT/GC electrode in the present study.

The linear range and LOD values obtained in the present study were also compared with those of the liquid chromatographic and spectrophotometric methods used for the determination of RIF (Table 4). According to the results, the linear range was wider and LOD values were lower for both DPV and SWV compared to the studies in Table $4 .^{39-44}$

\section{CONCLUSION}

The electrochemical behavior of RIF was studied in the anodic direction by using MWCNT-modified GC electrodes. Modification was done by coating of $1.5 \mu \mathrm{L}$ of $0.2 \%\left(\mathrm{mg} \mathrm{mL}^{-1}\right)$ MWCNT/ DF dispersion on the surface of a GC electrode. The anodic process of RIF was irreversible and diffusion controlled in AcB at $\mathrm{pH} 3.5$ as supporting electrolyte. Determination studies were carried out with DPV and SWV. These validated techniques enabled selective, rapid, sensitive, and cheap determination of RIF. RIF was also sensitively determined in its pharmaceutical dosage forms without any separation steps. The results showed that the inactive excipients caused no interference during the voltammetric measurements. The results obtained in the present study were compared with those of both other electrochemical sensors and the liquid chromatographic and spectrophotometric methods proposed for RIF. The proposed DPV and SWV techniques using MWCNT-modified GC electrodes were more sensitive, cheaper, simpler, and faster determination methods for RIF. They might be alternatives to the liquid chromatographic and spectrophotometric methods in therapeutic drug monitoring.

\begin{tabular}{|c|c|c|c|}
\hline Method & Medium & Linear range, $\mu \mathrm{g} / \mathrm{mL}$ & $\mathrm{LOD}, \mu \mathrm{g} / \mathrm{mL}$ \\
\hline RP-HPLC 39 & Methanol:acetonitrile: water $(60: 20: 20, v / v)$ & $40-100$ & 0.5 \\
\hline HPLC 40 & $\begin{array}{l}20 \mathrm{mM} \text { monobasic sodium phosphate buffer with } 0.2 \% \text { triethylamine } \\
(\mathrm{pH} 7.0) \text { :acetonitrile }(96+4, \mathrm{v} / \mathrm{v})\end{array}$ & $105-195$ & - \\
\hline RP-HPLC 41 & Acetonitrile:methanol:water (30:5:65, v/v, pH 5.2) & $60-150$ & 0.13 \\
\hline UV spectrophotometry ${ }^{42}$ & Folin-Ciocalteu reagent (FCR) & $1.0-35$ & 0.32 \\
\hline UV spectrophotometry ${ }^{43}$ & Methanol & $5-50$ & 2.30 \\
\hline UV spectrophotometry ${ }^{44}$ & Ethyl acetate solution & $2.5-35.0$ & 0.83 \\
\hline DPV (this work) & \multirow{2}{*}{ AcB, pH 3.5} & \multirow{2}{*}{$0.033-8.23$} & $6.18 \times 10^{-3}$ \\
\hline SWV & & & $9.11 \times 10^{-3}$ \\
\hline
\end{tabular}

RIF: Rifampicin, RP-HPLC: Reversed phase-high performance liquid chromatography, UV: Ultraviolet, DPV: Differential pulse voltammetry, SWV: Square wave voltammetry, LOD: Limits of detection, AcB: Acetate buffer

\section{REFERENCES}

1. Hardman JG, Limbird LE. Goodman and Gilman's The Pharmacological Basis of Therapeutics ( $9^{\text {th }}$ ed). In: Molinoff PB, Ruddon RW, eds. New York; Mc-Graw-Hill; 1996:1160.

2. Campbell EA, Korzheva N, Mustaev A, Murakami K, Nair S, Goldfarb A, Darst SA. Structural mechanism for rifampicin inhibition of bacterial RNA polymerase. Cell. 2001;104:901-912.

3. Takahashi K, Tatsumi N, Fukami T, Yokoi T, Nakajima M. Integrated analysis of rifampicin-induced microRNA and gene expression changes in human hepatocytes. Drug Metab Pharmacokinet. 2014;29:333-340.

4. Eswaran S, Adhikari AV, Chowdhury IH, Pal NK, Thomas KD. New quinoline derivatives: Synthesis and investigation of antibacterial and antituberculosis properties. Eur J Med Chem. 2010;45:3374-3383.

5. World Health Organization, WHO Model Prescribing Information: Drugs Used in Mycobacterial Diseases. Geneva; 1991.

6. Liu J, Sun J, Zhang W, Gao K, He Z. HPLC determination of rifampicin and related compounds in pharmaceuticals using monolithic column. J Pharm Biomed Anal. 2008;46:405-409.
7. Allanson AL, Cotton MM, Tettey JNA, Boyter AC. Determination of rifampicin in human plasma and blood spots by high performance liquid chromatography with UV detection: A potential method for therapeutic drug monitoring. J Pharm Biomed Anal. 2007;44:963-969.

8. Goutal S, Auvity S, Legrand T, Hauquier F, Cisternino S, Chapy H, Saba W, Tournier N. Validation of a simple HPLC-UV method for rifampicin determination in plasma: Application to the study of rifampicin arteriovenous concentration gradient. J Pharm Biomed Anal. 2016;123:173-178.

9. Grégoire M, Leroy AG, Bouquié R, Malandain D, Dailly E, Boutoille D, Renaud C, Jolliet P, Caillon J, Deslandes G. Simultaneous determination of ceftaroline, daptomycin, linezolid and rifampicin concentrations in human plasma by on-line solid phase extraction coupled to highperformance liquid chromatography-tandem mass spectrometry. J Pharm Biomed Anal. 2016;118:17-26.

10. Fang PF, Cai HL, Li HD, Zhu RH, Tan QY, Gao W, Xu P, Liu YP, Zhang WY, Chen YC, Zhang F. Simultaneous determination of isoniazid, rifampicin, levofloxacin in mouse tissues and plasma by high performance 
liquid chromatography-tandem mass spectrometry. J Chromatogr B. 2010;878:2286-2291.

11. Vu DH, Koster RA, Bolhuis MS, Greijdanus B, Altena RV, Nguyen DH, Brouwers JRBJ, Uges DRA, Alffenaar JWC. Simultaneous determination of rifampicin, clarithromycin and their metabolites in dried blood spots using LC-MS/MS. Talanta. 2014;121:9-17.

12. Chellini PR, Mendes TO, Franco PHC, Porto BLS, Tippavajhala VK, César IC, Oliveira MAL, Pianetti GA. Simultaneous determination of rifampicin, isoniazid, pyrazinamide and ethambutol in 4-FDC tablet by Raman spectroscopy associated to chemometric approach. Vib Spectrosc. 2017;90:14-20.

13. Salem AA, Mossa HA, Barsoum BN. Quantitative determinations of levofloxacin and rifampicin in pharmaceutical and urine samples using nuclear magnetic resonance spectroscopy. Spectrochim Acta A Mol Biomol Spectrosc. 2005;62:466-472.

14. Benetton SA, Kedor-Hackmann ER, Santoro MI, Borges VM. Visible spectrophotometric and first-derivative UV spectrophotometric determination of rifampicin and isoniazid in pharmaceutical preparations. Talanta. 1998;47:639-643.

15. Hammam E, Beltagi AM, Ghoneim MM. Voltammetric assay of rifampicin and isoniazid drugs, separately and combined in bulk, pharmaceutical formulations and human serum at a carbon paste electrode. Microchem J. 2004;77:53-62.

16. Kawde AN, Temerk Y, Farhan N. Adsorptive stripping voltammetry of antibiotics rifamycin SV and rifampicin at renewable pencil electrodes. Acta Chim Slov. 2014;61:398-405.

17. Gan T, Shi Z, Wang K, Sun J, Lv Z, Liu Y. Rifampicin determination in human serum and urine based on a disposable carbon paste microelectrode modified with a hollow manganese oxideamesoporous silica oxide core-shell nanohybrid. Can J Chem. 2015;93:1061-1068.

18. Tyszczuk K, Korolczuk M. New protocol for determination of rifampicine by adsorptive stripping voltammetry. Electroanalysis. 2009;21:101-106.

19. Rastgar S, Shahrokhian S. Nickel hydroxide nanoparticles-reduced graphene oxide nanosheets film: Layer-by-layer electrochemical preparation, characterization and rifampicin sensory application. Talanta. 2014;119:156-163.

20. Asadpour-Zeynali K, Mollarasouli F. Novel electrochemical biosensor based on PVP capped $\mathrm{CoFe}_{2} \mathrm{O}_{4} \mathrm{aCdSe}$ core-shell nanoparticles modified electrode for ultra-trace level determination of rifampicin by square wave adsorptive stripping voltammetry. Biosens Bioelectron. 2017;92:509-516.

21. Gutierrez-Fernandez S, Blanco-Lopez MC, Lobo-Castanon MJ, MirandaOrdieres AJ, Tunon-Blanco P. Adsorptive stripping voltammetry of rifamycins at unmodified and surfactant-modified carbon paste electrodes. Electroanalysis. 2004;16:1660-1666.

22. Hahn Y, Shin S. Electrochemical behavior and differential pulse polarographic determination of rifampicin in the pharmaceutical preparations. Arch Pharm Res. 2001;24:100-104.

23. Alonso Lomillo MA, Dominguez Renedo O, Arcos Martinez MJ. Optimization of the experimental parameters in the determination of rifampicin by adsorptive stripping voltammetry. Electroanalysis. 2002;14:634-637.

24. Balasubramanian K, Burghard M. Chemically functionalized carbon nanotubes. Small. 2005;1:180-192.
25. Rivas GA, Rubianes MD, Rodriguez MC, Ferreyra NF, Luque GL, Pedano ML, Miscoria SA, Parrado C. Carbon nanotubes for electrochemical biosensing. Talanta. 2007;74:291-307.

26. lijima S. Carbon nanotubes: Past, present, and future. Physica B. 2002;323:1-5.

27. Method Validation in Pharmaceutical Analysis. In: Ermer J, Miller JH, eds. Veinheim; Wiley-VCH; 2005.

28. Bievre P, Günzler H. Validation in Chemical Measurements. New York; Springer; 2005.

29. Kul D. Sensitive and selective determination of tolterodine tartrate and its electrochemical investigation on solid carbon based electrodes. J Anal Chem. 2014;69:970-981.

30. Laviron E, Roullier L, Degrand C. A multilayer model for the study of space distributed redox modified electrodes: Part II. Theory and application of linear potential sweep voltammetry for a simple reaction. J Electroanal Chem Interfacial Electrochem. 1980;112:11-23.

31. Validation of Active Pharmaceutical Ingredients ( $2^{\text {nd }}$ ed). In: Berry IR, Harpaz D, eds. Washington; CRC Press; 2001.

32. Yi LH, Li JN, Gao P. Anodic adsorptive voltammetric determination of rifampicin at a carbon paste electrode. Nat Sci J Xiangran Univ. 2005;27:108-111.

33. Chokkareddy R, Bhajanthri NK, Redhi GG. A novel electrode architecture for monitoring rifampicin in various pharmaceuticals. Int J Electrochem Sci. 2017;12:9190-9203.

34. Amidi S, Hosseinzadeh Ardakani Y, Amiri-Aref M, Ranjbari E, Sepehri Z, Bagheri H. Sensitive electrochemical determination of rifampicin using gold nanoparticles/poly-melamine nanocomposite. RSC Advances. 2017;7:40111-40118.

35. Shiri S, Pajouheshpoor N, Khoshsafar H, Amidi S, Bagheri H. An electrochemical sensor for the simultaneous determination of rifampicin and isoniazid using a C-dots $\mathrm{CCuFe}_{2} \mathrm{O}_{4}$ nanocomposite modified carbon paste electrode. New J Chem. 2017;41:15564-15573.

36. Lomillo MAA, Renedo OD, Martinez MJA. Optimization of the experimental parameters in the determination of rifampicin by adsorptive stripping voltammetry. Electroanalysis. 2001;14:634-637.

37. Lomillo MAA, Renedo OD, Martinez MJA. Optimization procedure, applying the experimental-design methodology, for the determination of rifampicin after metal complexation by differential pulse adsorptive stripping voltammetry. Helv Chim Acta. 2002;85:2430-2439.

38. Leandro KC, de Carvalho JM, Giovanelli LF, Moreira J. Development and validation of an electroanalytical methodology for determination of isoniazid and rifampicin content in pharmaceutical formulations. Braz $\mathrm{J}$ Pharm Sci. 2009;45:331-337.

39. Kumari MK, Kasthuri JK, Babu BH, Satyanarayana PVV, Tchaleu BN. A validated liquid chromatographic method for the determination of rifampicin and isoniazid in pharmaceutical formulations. Brit J Pharm Res. 2015;7:299-307.

40. Chellini PR, Lages EB, Franco PHC, Nogueira FHA, César IC, Pianetti GA. Development and validation of an HPLC method for simultaneous determination of rifampicin, isoniazid, pyrazinamide, and ethambutol hydrochloride in pharmaceutical formulations. J AOAC Int. 2015;98:1234-1239.

41. Prasanthi B, Vijaya Ratna J, Ch. Phani RS. Development and validation of RP-HPLC method for simultaneous estimation of rifampicin, isoniazid and pyrazinamide in human plasma. J Anal Chem. 2015;70:1015-1022. 
42. Swamy N, Basavaiah K. Spectrophotometric determination of rifampicin in bulk drug and pharmaceutical formulations based on redox and complexation reactions. J Appl Spectros. 2017;84:694-703.

43. Tilinca M, Hancu G, Mircia E, Iriminescu D, Rusu A, Vlad RA, Barabas E. Simultaneous determination of isoniazid and rifampicin by UV spectrophotometry. Farmacia. 2017;65:219-224.
44. Khan MF, Rita SA, Kayser MS, Islam MS, Asad S, Bin Rashid R, Bari MA, Rahman MM, Al Aman DAA, Setu NI, Banoo R, Rashid MA. Theoretically guided analytical method development and validation for the estimation of rifampicin in a mixture of isoniazid and pyrazinamide by UV spectrophotometer. Front Chem. 2017;5:27. 